\title{
RETORYKA STRACHU W CZASIE PANDEMII COVID-19. PRZYPADEK EMMANUELA MACRONA
}

\author{
RHETORIC OF FEAR DURING THE COVID-19 PANDEMIC: \\ THE CASE OF EMMANUEL MACRON
}

Sylwia Frach* (ㅇ

\begin{abstract}
ABSTRAKT
Artykuł prezentuje wyniki analizy telewizyjnego orędzia prezydenta Francji Emmanuela Macrona z dnia 16 marca 2020 roku. Stanowi ono przyczynek do wskazania na znaczenie we współczesnym dyskursie politycznym odwoływania się do logiki strachu i poczucia zagrożenia. Analiza treści pozwoliła wskazać najważniejsze cechy retoryki strachu, jaka zdominowała prezydenckie przemówienie pełne sensacyjnych metafor i wojennych odniesień, będących doskonałym przykładem moralnej paniki w czasie kryzysu, w którym zwiększa się zapotrzebowanie na informację. Analizą dyskursu objęto leksykalne i składniowe środki językowe, gdzie niezwykle częste metafory wojenne dają możliwość manipulacji opinią społeczną i wdrażania koncepcji uodpowiedzialnienia obywateli.
\end{abstract}

Słowa kluczowe: panika moralna; krytyczna analiza dyskursu; kwestia polityczna; Francja; pandemia
The article presents the results of the analysis of the speech of President Emmanuel Macron on March 16, 2020 on French TV. It indicates the importance of referring to the logic of fear and the sense of threat in contemporary political discourse. The analysis of the content allowed to identify the most important features of the rhetoric of fear that dominated the presidential speech full of sensational metaphors and war references, which are an excellent example of moral panic in a crisis when the demand for information increases. The discourse analysis covers lexical and syntactic linguistic means, where extremely frequent war metaphors enable the manipulation of social opinion and the implementation of the concept of citizens' responsibility.

Keywords: moral panic; critical discourse analysis; political issue; France; pandemic

* Uniwersytet Opolski, Wydział Nauk o Polityce i Komunikacji Społecznej. 


\section{WPROWADZENIE}

W 1972 roku brytyjski socjolog Stanley Cohen, w pracy Folk Devils and Moral Panics: The Creation of the Mods and Rocker, podjął próbę sformułowania definicji „paniki moralnej”. Według Cohena panika moralna odnosi się do „stanu, wydarzenia, osoby lub grupy osób, [które] zaczynają być określane jako zagrożenie dla wartości i interesów społecznych; ich charakter jest przedmiotem stylizacji i stereotypizacji przez media; redaktorzy, kaznodzieje, politycy i inne prawomyślne jednostki wznoszą moralne barykady; eksperci cieszący się społeczną akredytacją wygłaszają swoje diagnozy i wypisują recepty" (Cohen, 1972, s. 9). W przeciwieństwie do większości koncepcji socjologicznych panika moralna jest szeroko stosowana w środkach masowego przekazu; termin ten jest częścią współczesnego dyskursu publicznego, włączając język polityki. Panika moralna, zauważa David L. Altheide (2009, s. 81), często występuje w medialnych newsach i reportażach, odpowiada bowiem sposobom selekcji, organizacji i prezentowania informacji, kształtując zapotrzebowanie publiczności na pewnego rodzaju informacje (por. Thompson, 1999; Critcher, 2003). Wiąże się to $\mathrm{z}$ narracją strachu (inaczej zwaną dyskursem strachu), która jest związana $\mathrm{z}$ tym, że zagrożenie i ryzyko są centralną cechą symbolicznego środowiska, definiując doświadczenie codziennej egzystencji. Często wiąże się to z doniesieniami o przestępczości, przemocy i wiktymizacji (Altheide, 2009, ss. 81-82). Jak podkreśla Andreja Zevnik (Zevnik, 2017, s. 235), nowoczesna rzeczywistość polityczna jest w coraz większej mierze nasycona świadectwami i reprezentacjami społecznych i osobistych lęków. Najczęściej tym narracjom towarzyszy pragnienie zidentyfikowanie i wdrożenie „leku”, który uśmierzy lub wymaże źródło dyskomfortu. W codziennej polityce taki „lek” przybiera postać nowej polityki lub prawa. Jak ujmuje to Zygmunt Bauman, „poczucie bezsilności - ta najbardziej przerażająca konsekwencja strachu - tkwi jednak nie w postrzeganych czy wyczuwanych zagrożeniach jako takich, lecz w rozległej, ale bardzo nędznie zagospodarowanej przestrzeni rozpościerającej się pomiędzy zagrożeniami, z których emanują lęki, a naszymi reakcjami - reakcjami dostępnymi i/lub uznanymi za realistyczne" (Bauman, 2006, s. 40). We współczesnych społeczeństwach neoliberalnych mamy do czynienia z wyłonieniem się swoistej kultury strachu (Czapnik, 2019, s. 73), podsycanej przez logikę mediów cyfrowych (Altheide, 2020, s. 516).

Istotne w tym kontekście jest odwołanie się do myśli Michela Foucaulta. Według Foucaulta biopolityka (biopolitique) uznaje populację za „problem polityczny”, który wymaga „regularyzacji” (régularisation). Operuje w stosunku 
do normalizacji i/lub optymizacji cielesnych dyscyplin (anatomo-polityka) jednostek w życiu codziennym. Biowładza, synteza biopolityki i anatomo-polityki, jest najważniejszym wyrazem władzy w epoce nowoczesnej (Nadesan, 2008, s. 211). Tu wyłania się kategoria rządomyślności (gouvernmentalité), która ukazuje roboczą hipotezę Foucaulta o wzajemnej konstytucji technik władzy i form wiedzy. Semantyczne połączenie rządzenia (gouverner) i sposobów myślenia (mentalité) świadczy o tym, że nie sposób badać technologii władzy bez analizy politycznej racjonalności, która leży u ich podstaw. Istnieją dwie strony czy też „sztuki rządzenia”. Jedną ze stron rządomyślności jest specyficzna forma reprezentacji - rząd definiuje dyskursywne pole sprawowania władzy, który jest „zracjonalizowany”. Odbywa się to na wiele sposobów, w tym poprzez specyfikację obiektów i granic, dostarczanie argumentów i usprawiedliwień. Rząd przedstawia problem, oferując różne strategie radzenia sobie z nim (Lemke, 2001, s. 191).

Trzeba zdawać sobie sprawę, że neoliberalnej wolności towarzyszy dyskurs „uodpowiedzialnienia” (responsabilisation). Jako iż ludzie mogą korzystać ze swej wolności w sposób nieproduktywny lub nawet destrukcyjny, wyłania się jedna z kluczowych technologii neoliberalizmu, a mianowicie uodpowiedzialnienie. Uodpowiedzialnienie zachodzi poprzez normy prawne, moralne potępienie, nieformalne sankcje i różne konwencje. Dzięki temu jednostki są podmiotami, które uznają siebie za wolne i odpowiedzialne za własne działania i ich skutki (Biebricher, Vance Johnson, 2012, s. 205). Uodpowiedzialnione społeczeństwo nie ujmuje jednostek jako ulokowanych społecznie, lecz autonomicznych aktorów, którzy dokonują wyborów określających ich własne życie. Autonomia i wybór, jakkolwiek fundamentalne dla neoliberalnej reprezentacji jaźni, nie zawsze są pożądane (Trnka, Trundle, 2014, s. 139). Rzecz jasna, nie powinno się w tym kontekście zapominać o nierówności klasowej (Blackshaw, 2016, s. 13), a także przestrodze Zygmunta Baumana, iż „socjologia, która w [jego] przekonaniu winna w warunkach indywidualizacji społeczeństwa stać się ‘wolnościologią’”, jest z natury rzeczy uprawniona, a i wręcz zobowiązana, do 'patrzenia państwu (jak i wszystkim innym mocom wolność krępującym) na palce'” (Bauman, Czapnik, 2016, s. 16).

Celem tekstu jest analiza orędzia prezydenta Francji Emmanuela Macrona z 16 marca 2020 roku - wybrano to przemówienie ze względu na jego programowy charakter, szeroki odzew w mediach i w społeczeństwie francuskim - które daje możliwość prześledzenia pewnych ogólniejszych tendencji dyskursywnych. Tezą artykułu jest, iż owo przemówienie stanowi przykład kierowania się przez 
decydentów politycznych logiką strachu i poczucia zagrożenia. Innymi słowy, to orędzie jest egzemplifikacją tendencji dyskursywnych.

W tym kontekście konieczne jest zrozumienie narzędzi stosowanych przez przywódców politycznych podczas ich wystąpień w sytuacjach kryzysowych, dominującej w nich retoryki strachu, której podporządkowane są słowa. Co więc sprawia, że komunikacja w sytuacji naznaczonej kryzysem jest tak wyjątkowa?

\section{METODOLOGIA KRYTYCZNEJ ANALIZY DYSKURSU}

Wydaje się zasadne, aby omawianą materię analizować przez pryzmat krytycznej analizy dyskursu (critical discourse analysis). Krytyczna analiza dyskursu obejmuje wszelkie szeroko rozumiane teksty, włącznie z przemówieniami politycznymi. Badacze dyskursu przyjmują, iż jest on formą użycia języka. Funkcjonalna definicja wskazuje na dyskurs jako zdarzenie komunikacyjne. Teun A. van Dijk zauważa, iż „oznacza to, że ludzie używają języka, by przekazywać różne idee i przekonania (lub by wyrażać emocje). Robią to zaś w ramach wyznaczonych przez przebieg bardziej złożonych sytuacji społecznych" (van Dijk, 2001, s. 10).

Van Dijk wskazuje na dwa tryby komunikacji: wypowiedzi i teksty. Mowa (dyskurs mówiony) obejmuje codzienne rozmowy i inne odmiany dialogu, w tym debaty parlamentarne, spotkania rad nadzorczych czy kontakty lekarzy z pacjentami. Tekst (czyli dyskurs pisany) stanowi określenie ogromnego zbioru różnorodnych dyskursów, zawierającego informacje zamieszczone w prasie, artykuły naukowe, powieści, podręczniki szkolne i akademickie oraz ogłoszenia. W sensie bardziej technicznym kategoria „tekst” niekiedy jest używana w analizie dyskursu w odniesieniu abstrakcyjnej (ukrytej) struktury dyskursu bądź transkrypcyjnego zapisu wypowiedzi (van Dijk, 2001, s. 15).

Powtórzmy za van Dijkiem, że „ludzie są w stanie zrozumieć zdanie, osiągnąć spójność między zdaniami albo uchwycić sens tekstu pod warunkiem, że podzielają pewien wspólny repertuar społeczno-kulturowych przekonań. Wybór jednostek leksykalnych, alternacje stylistyczne, użycie środków retorycznych - wszystko to implikuje, że użytkownicy języka wyrażają swoje opinie lub ideologie, a także wnoszą swój wkład w tworzenie nowych lub przekształcanie już istniejących" (pisownia oryginału) (van Dijk, 2001, s. 26).

Warto zaznaczyć, iż krytyczna analiza dyskursu wywodzi się z marksizmu, strukturalizmu oraz hermeneutyki. Pośród jej korzeni niebagatelną rolę odegrała teoria krytyczna szkoły frankfurckiej (zwłaszcza podejście Jürgena Habermasa), 
a także prace Michela Foucaulta. Od niemieckiego filozofa przejęto założenie, iż język może - i jest - być wykorzystywany do swoich partykularnych celów przez grupy sprawujące władzę, zaś od francuskiego myśliciela zaczerpnięto konstatację, że w obręb dyskursu należy włączyć elementy niewerbalne, w tym różnorakie uwarunkowania kontekstowe oraz założenie o dyskursie jako działaniu społecznym, czyli języku w użyciu (Warzecha, 2014, s. 166).

Trafne wydaje się spostrzeżenie Adama Warzechy, wedle którego krytyczna analiza dyskursu ,interesuje się przede wszystkim nierównościami społecznymi, które wynikają z różnic między ludźmi (między innymi takimi jak płeć, pochodzenie etniczne i środowiskowe, przynależność klasowa, religia, język, orientacja seksualna i inne). Uwydatniają to podejmowane w jej ramach zagadnienia asymetrii władzy, wyzysku, wykorzystania, manipulacji i strukturalnych nierówności. Oprócz analizy dyskursu politycznego i ekonomicznego, które stanowią naturalne środowisko tego nurtu" (Warzecha, 2014, s. 169).

Norman Fairclough (Fairclough, 1989, s. 46) zwraca uwagę na istotne zagadnienie władzy w dyskursie - potężni uczestnicy kontrolują i ograniczają pozostałych. Można wyróżnić trzy typy tego typu ograniczeń. Pierwsze dotyczą zawartości - tego, co jest mówione lub czynione. Drugie dotyczą stosunków relacji społecznych łączących ludzi wchodzących w dyskurs. Trzecie odnoszą się do podmiotów - pozycji, jaką dane podmioty mogą zajmować.

Fairclough w apelu z roku 2000 podkreśla, że nowy porządek - porządek neoliberalnego, zglobalizowanego kapitalizmu - ma również istotny wymiar językowy, wiąże się bowiem z koniecznością narzucenia nowych reprezentacji świata, nowych dyskursów. Oznacza to, że walka z nim również powinna odbywać się na niwie językowej (Fairclough, 2000, s. 147). Język - szerzej: semioza - przejawia się na dwa główne sposoby w materialnych procesach społecznych. Po pierwsze jako element tych procesów dialektycznie połączony z innymi elementami. Po drugie jako refleksyjne konstrukcje tych procesów, które aktorzy społeczni produkują w ramach owych procesów. Nowy porządek nie jest równoznaczny z homogenizacją - to specyficzna struktura różnicy (włączając w to opór) (Fairclough, 2000, ss. 147-148).

Eve Chiapello i Fairclough (Chiapello, Fairclough, 2002, s. 193) zwracają uwagę, iż krytyczna analiza dyskursu opiera się na uznaniu semiozy za nieredukowalny element wszelkich materialnych procesów społecznych. Życie społeczne jest połączone sieciami praktyk społecznych różnego rodzaju - gospodarczych, politycznych, kulturalnych, rodzinnych etc. Koncepcja praktyki społecznej pozwala na oscylowanie między dwiema koniecznymi perspektywami społecz- 
nych badań - perspektywą struktury społecznej i społecznego działania. Praktyka społeczna to stosunkowa ustabilizowana forma aktywności społecznej. Innymi słowy, ,„każda praktyka jest wyrazem różnych elementów społecznych w stosunkowo stabilnej konfiguracji, zaś jej elementem zawsze jest dyskurs. Można by rzec, iż każda praktyka zawiera takie elementy, jak: aktywności, podmioty i ich stosunki społeczne, narzędzia, przedmioty, czas i miejsce, formy świadomości, wartości, dyskurs (lub semiozę)” (Chiapello, Fairclough, 2002, s. 193).

Stosunek pomiędzy dyskursem a innymi elementami praktyk społecznych jest stosunkiem dialektycznym - dyskurs internalizuje i jest internalizowany przez inne elementy, z których żadnego nie sposób zredukować do pozostałych. Jeżeli spojrzeć na dialektykę dyskursu w kategoriach historycznych, w kategoriach procesów zmiany społecznej, pojawia się pytanie o sposoby i warunki procesów owej internalizacji (Chiapello, Fairclough, 2002, s. 195).

\section{WOJENNE ORĘDZIE EMMANUELA MACRONA A NEOLIBERALIZM JAKO PRAKTYKA DYSKURSYWNA}

W swoim orędziu telewizyjnym wygłoszonym w poniedziałek 16 marca 2020 roku o godzinie 20:00 - drugim od pięciu dni - prezydent Francji zapowiedział wprowadzenie przepisów o bezprecedensowym radykalizmie $\mathrm{w}$ walce $\mathrm{z}$ pandemią koronawirusa. „Francja nigdy nie musiała podejmować tak wyjątkowych decyzji, oczywiście tymczasowych w czasie pokoju” - zaznaczył na wstępie Macron.

Adrien Rivierre (Rivierre, 2020), specjalista od wystąpień publicznych, na łamach francuskiego dziennika ekonomicznego Les Échos podkreślił, że telewizyjne orędzie prezydenta Macrona bez wątpienia przejdzie do historii (przynajmniej tego kryzysu sanitarnego) dzięki powtarzanej we wszystkich mediach anaforze „Jesteśmy w stanie wojny” („Nous sommes en guerre”). Emmanuel Macron użył terminu „wojna” aż siedem razy: pięć razy w wyrażeniu „Jesteśmy w stanie wojny”, raz w zdaniu, któremu towarzyszy końcowe „tak” („Nous sommes en guerre, oui”) i raz zestawiając dwa sprzeczne ze sobą fakty - „W wojnie o zdrowie oczywiście” („En guerre sanitaire, certes”). Ton wojenny miał na celu wywołanie „ogólnej mobilizacji” przeciwko „niewidzialnemu, nieuchwytnemu wrogowi (...)”. Prezydent użył słownictwa należącego do pola semantycznego wyrazu „wojna” (guerre): „wojna o zdrowie” (guerre sanitaire), ,walka” (combat, dwukrotnie), „powszechna mobilizacja” (mobilisation generale), „unia narodowa” (union 
nationale), „armia” (armée, trzykrotnie). Użycie słowa „armia” występuje rzadziej niż użycie słowa „wojna”, jednakże jego konotacja z wojną jest nieunikniona dla przeciętnego obywatela. Termin „armia” pojawia się po raz pierwszy w przemówieniu w liczbie pojedynczej i wyjaśnia ideę „wojny o zdrowie” - „nie walczymy ani $z$ armią, ani z narodem” („nous ne luttons ni contre une armée, ni contre une Nation”). Zwrot „wojna o zdrowie” tworzy pewien obraz w ramach retoryki wojny wewnętrznej użytej do celów politycznych. W tym zdaniu termin „armia” nie jest bezpośrednio związana z czasownikiem odnoszącym się do konkretnej czynności lub akcji. Jest to zabieg pragmatyczny: przemówienie prezydenckie minimalizuje znaczenie wojska w celu zapewnienia obywateli o ciągłości władzy demokratycznej. Następnie pojęcie to pojawia się w liczbie mnogiej w wyrażeniu stałym - „Szpital polowy Wojskowej Służby Zdrowia” („Un hôpital de campagne du service de santé des armées") i jeszcze raz w liczbie mnogiej, ale tylko raz, aby odnieść się bezpośrednio do armii francuskiej, „Wojska zapewnią pomoc w przemieszczaniu chorych...” („Les armées apporteront leur concours pour déplacer les malades...”). Należy również zauważyć, że terminy „armia” i „wojna” występują wspólnie w jednym zdaniu, „Jesteśmy w stanie wojny, wojny o zdrowie oczywiście: nie walczymy z armią ani z narodem” („Nous sommes en guerre, en guerre sanitaire, certes: nous ne luttons ni contre une armée, ni contre une Nation"). To współistnienie w ramach tego samego zdania jest wyjątkowe (nie powtarza się w przemówieniu), a co za tym idzie - jest kluczowe z jakościowego punktu widzenia - opiera się na nim cała narracja strachu. Dyskurs budowany na wojennych metaforach - mówiąc o „froncie”, „linii frontu” i wzywając wszystkich do „mobilizacji” - służy nie tylko wyjaśnieniu sytuacji, ale i perswazji.

Należy podkreślić, że kategorią dorozumianą w przemówieniu Macrona jest strach. Nie jest to bynajmniej przypadkiem. Powtórzmy za Piotrem Francuzem (Francuz, 2007, ss. 214-215), że „zgodnie z definicją Amerykańskiego Towarzystwa Psychiatrycznego strach jest trwożnym przewidywaniem przyszłych zagrożeń lub nieszczęść, któremu towarzyszą somatyczne objawy napięcia [...] oraz poczucie przygnębienia, obniżonego nastroju lub depresji. Strach jest silnym motywatorem działań (np. ucieczki lub ataku), wywołanym przez rozpoznawalny bodziec".

Macron zdaje się podążać śladem klasycznego teoretyka wojny, Carla von Clausewitza (1958, s. 18), który przekonywał, że w zwycięstwie w wojnie kluczową rolę odgrywają zasób posiadanych środków oraz napięcie siły woli. Bezsprzecznie rację ma pruski generał twierdzący, że wojna jest funkcją, przedłużeniem, instrumentem polityki (Winczewski, 2017, s. 152). 
Francuski prezydent wpisuje się w długą tradycję, w ramach której państwa w historii lękały się o bezpieczeństwo, z zapewnieniem go wiążąc fundamentalną strukturę własnego bytu. Pragnienie bezpieczeństwa leży u podstaw zachodniej filozofii politycznej i jej koncepcji suwerenności, tożsamości politycznej i samej państwowości. Dla Thomasa Hobbesa, od którego można wywieść kluczowe idee, które legły u podstaw nowoczesnego państwa-narodu, pragnienie zapewnienia bezpieczeństwa motywowało ludzi do ustanowienia państw i praw, podporządkowania się suwerenowi, wraz z którym tworzy się ciało polityczne (Burke, 2008, ss. 1-2).

Rivierre wskazał podobieństwa między orędziem Emmanuela Macrona a przemówieniami historycznymi znanych przywódców, takich jak generał de Gaulle czy Winston Churchill. W celu wzmocnienia siły przekazu Macron przemawiał w swoim własnym imieniu z masowym użyciem zaimka osobowego „ja” (je) aż 32 razy. Warto uwypuklić tutaj - za Franzem L. Neumannem (Neumann, 2017, s. 618) - dwa fundamentalne rodzaje identyfikacji: afektywną i nieafektywną, uznając, że identyfikacja nieafektywna $z$ organizacją jest mniej regresywna od afektywnej identyfikacji z przywódcą. Co ważne, lojalność nieafektywną można przenieść, osobistą - nie. Ta pierwsza zawiera silne elementy racjonalistyczne, elementy kalkulacji pomiędzy organizacją i jednostką, co z kolei zapobiega totalnej destrukcji ja. W ramach identyfikacji afektywnej można wyróżnić dwa typy, które można określić mianem kooperatywnego i cezarystycznego. W pewnych momentach dziejów - i w niewielkich grupach - zdarzało się, że wiele równych jednostek utożsamiło się kooperacyjnie ze sobą w taki sposób, że ich ja złączyło się w ja kolektywne. Cezarystyczna identyfikacja to identyfikacja mas z przywódcami, to najbardziej regresywna forma, zbudowana na nieomal całkowitym wyzbyciu się własnego ja.

W duchu Foucaulta prezydent poprzez mechanizm „uodpowiedzialnienia” skupił się na wysiłku i dyscyplinie, zarówno indywidualnej, jak i zbiorowej, którą Francuzi musieli się wykazać, pozostawiając w sferze niepewności przykłady środków, jakie należało podjąć. „W czasie, gdy sytuacja zdrowotna gwałtownie się pogarsza (...), całe nasze zaangażowanie, cała nasza energia, cała nasza siła musi być skupiona na jednym celu: spowolnieniu postępu wirusa. Powtarzam wam to mocno dziś wieczorem: szanujmy gesty barierowe, instrukcje sanitarne". Na terytorium Francji dozwolone zostały tylko najbardziej newralgiczne wyjścia: do lekarza, do pracy (gdy praca zdalna nie była możliwa), oraz by zażyć nieco aktywności fizycznej. Emmanuel Macron zaapelował do Francuzów, aby nie ulegali panice i zachowali zdrowy rozsądek. „Żadna firma nie zostanie nara- 
żona na ryzyko bankructwa, żadna Francuzka, żaden Francuz nie pozostanie bez zasobów" - zapewnił prezydent. Macron zapowiedział utworzenie funduszu solidarnościowego w wysokości 300 mld euro, które zostaną przeznaczone na pożyczki dla małych przedsiębiorstw.

Zastanawiające jest, że strach przed wirusem w pewien istotny sposób przypomina strach przed przestępczością. Większe znaczenie od samej pandemii ma uczucie strachu przed nią, wpływając na wybory dokonywane przez obywateli, umożliwiając władzom określone sposoby zarządzania nimi (Simon, 2007, ss. 6-7).

Należy nadmienić, iż orędzie prezydenta Republiki próbuje odnieść się do solidnie ugruntowanego w popularnym myśleniu „tego, co każdy wie”, bierze za dane lub zgadza się - mądrością ludową danej epoki. Jak ujmują to Stuart Hall i Allan O'Shea (Hall, O’Shea, 2013, s. 9), faktycznie politycy, odwołując się od opinii popularnej, w gruncie rzeczy kształtują ją i wpływają na nią. Przekonując, że opinia popularna już na coś się zgadza, tworzą porozumienie jako skutek swych działań, opierając się na mechanizmie samospełniającej się przepowiedni.

Można mniemać, że prezydent Francji próbuje przesłonić swoim zachowaniem fakt pewnej impotencji ekonomicznej i słabości władzy politycznej, bezradnej w obliczu niespodziewanych problemów. Wielu obywateli tego kraju, jakby to ujął Fredric Jameson, tracąc pracę, musi liczyć się z poczuciem nieproduktywności, które „jest wskaźnikiem sytuacji obiektywnej i niezmiennej, dlatego człowiek musi sobie z nią radzić inaczej: musi uznać jej trwałość i nieuchronność, czyli ukrywać, wypierać, przemieszczać i sublimować swoją zasadniczą, nieusuwalną bezsilność" (Jameson, 2011, s. 328).

Nakreślając obraz wojny, prezydent Francji spowodował natychmiastowe pojawienie się zachowań wojennych wśród ludności. Spodziewając się znacznego wzmocnienia kontroli, zwłaszcza w Paryżu, tysiące mieszkańców paryskiego regionu Ile-de-France opuściło stolicę jeszcze przed ogłoszeniem wprowadzenia obostrzeń.

Wypada w tym miejscu zwrócić uwagę na kwestie produkcji tekstu i podmiotu w dyskursie. Podmiot ma paradoksalne własności - jest społecznie zdeterminowany, lecz zdolny do stosowania jednostkowej kreatywności. Obraca się w kręgu pewnych kategorii, lecz jest zdolny przekształcać konwencje dyskursywne. Fairclough zaznacza, że społeczna determinacja i indywidualna kreatywność nie są przeciwieństwami, jakkolwiek jawią się jako takie (Fairclough, 1989, s. 169). 


\section{PANDEMIA COVID-19 I ŚCISŁA KWARANTANNA}

„Ta wojenna metafora prawdopodobnie nie była potrzebna. Byłoby rozsądniej użyć wyrażeń takich jak 'walka', 'zaraza, 'katastrofa' i uniknąć w ten sposób ciągłej potrzeby używania terminu 'wojna'. Rezultat i tak byłby taki sam” - napisał Patrick Martin-Genier na huffigtonpost.fr. Konsekwencją jest zatem wprowadzenie „stanu zagrożenia epidemicznego”. Rozporządzenie to przypomina, jeśli chodzi o podjęte środki, ustawę uchwaloną 3 kwietnia 1955 r. (w ferworze wojny algierskiej), która była kilkakrotnie nowelizowana w 2011 i 2015 roku, aby poradzić sobie z falą terroryzmu we Francji. Stan wyjątkowy, czy to stan zagrożenia epidemicznego, czy inny, jest stanem nadzwyczajnym, który na pewien czas ogranicza wolność publiczną. Ustawa ta daje władzy wykonawczej ogromne uprawnienia w zakresie prawa zwyczajowego i umożliwia ograniczenie wolności najbardziej chronionych w Republice Francuskiej: swobody przemieszczania się, swobody przedsiębiorczości, wolności zgromadzeń, wszelkich wolności chronionych Deklaracją Praw człowieka i Obywatela oraz preambułą do Konstytucji z 1958 roku.

Jak ujmuje to Paul Virilio, „gwałtowna SYNCHRONIZACJA emocji zbiorowości doskonale sprzyja zarządzaniu strachem. [...] Zarządzanie strachem, aby zapewnić bezpieczeństwo, pokój albo - przeciwnie - zarządzać nim, żeby wygrać wojnę domową - oto alternatywa, przed jaką stoi dziś psychopolityka narodów" (Virilio, 2007, s. 28).

$\mathrm{Na}$ antenie France 2, dr Damien Mascret wyjaśnił cel ścisłej kwarantanny, przedstawiając wartość dodaną obostrzenia, które ma na celu ograniczenie przemieszczania się ludzi, a tym samym spowolnienie epidemii. „Musimy wykonywać gesty barierowe, ale też ograniczać kontakty towarzyskie, zawodowe, rodzinne, przyjacielskie. To, co robimy dzisiaj, przyniesie rezultaty za 14 dni”, powiedział dr Mascret.

Francja zdecydowała się przeznaczyć 2 miliardy euro na walkę z koronawirusem - powiedział minister działań i rachunków publicznych Gérald Darmanin w wywiadzie dla Les Échos, gdzie szczegółowo opisał finansowanie „wysiłku wojennego" (effort de guerre) Francji przeciwko epidemii Covid-19, plan 45 miliardów euro nakreślony przez państwo w celu rozwiązania gospodarczych skutków pandemii. 


\section{PODSUMOWANIE}

W artykule skupiono się na analizie telewizyjnego orędzia prezydenta Francji Emmanuela Macrona z dnia 16 marca 2020 roku w związku z kryzysem wywołanym rozprzestrzenianiem się pandemii koronawirusa. Analiza treści pozwoliła wskazać najważniejsze cechy retoryki strachu, jaka zdominowała prezydenckie przemówienie pełne sensacyjnych metafor i wojennych odniesień, będących doskonałym przykładem moralnej paniki w czasie kryzysu. Analizą dyskursu objęto leksykalne i składniowe środki językowe, gdzie niezwykle częste metafory wojenne dają możliwość manipulacji opinią społeczną i wdrażania koncepcji uodpowiedzialnienia obywateli. Potwierdza to uwagę Fairclougha (Fairclough, 2000, s. 148), że prezydent Francji starał się w neoliberalny sposób problemy społeczne ukazywać w kategoriach indywidualnych. Odwołanie się do wartości uniwersalnych odgrywa rolę symbolicznej przemocy w myśl Pierre'a Bourdieu, która jednoczy nieświadomość zbiorową wokół takich zasad obywatelstwa, jak troska, szacunek i zaangażowanie.

\section{BIBLIOGRAFIA:}

Bauman, Z. (2006). Płynny lęk, przeł. Janusz Margański, Kraków: Wydawnictwo Literackie.

Bauman, Z., Czapnik, S. (2016). Jak słowo ciałem uczynić. Z Zygmuntem Baumanem rozmawia Sławomir Czapnik. Studia Krytyczne / Critical Studies, 2, 8-20.

Biebricher, T., Vance Johnson, E. (2012). What's Wrong with Neoliberalism? New Political Science, 34(2), 202-211. DOI: 10.1080/07393148.2012.676398.

Blackshaw, T. (2016). British Sociology, the Bourgeois Media-Sociology Hybrid and the Problem of Social Class, Studia Krytyczne / Critical Studies, 3, 13-43.

Burke, A. (2008). Fear of Security: Australian Invasion Anxiety, Cambridge-New York: Cambridge University Press.

Chiapello, E., Fairclough, N. (2002). Understanding the new management ideology: a transdisciplinary contribution from critical discourse analysis and new sociology of capitalism. Discourse \& Society, 13(2), 185-208.

Clausevitz, C. von. (1958), O wojnie, t. 1, Warszawa: Wydawnictwo Ministerstwa Obrony Narodowej.

Cohen, S. (1972). Folk Devils and Moral Panics: The Creation of the Mods and Rocker, Oxford: Martin Robertson.

Covid-19: „anxiogène”, „trop important”... Les Français jugent sévèrement le traitement de l'épidémie dans les medias. France info (2020). Pobrane z: https://www.francetvinfo. fr/economie/medias/covid-19-anxiogene-trop-important-les-francais-jugentseverement-le-traitement-de-l-epidemie-dans-les-medias_4118085.html. 
Critcher, Ch. (2003). Moral Panics and the Media, Philadelphia: Open University Press.

Czapnik, S. (2019). Przestrzenie polityki w myśli teoretycznej późnego Zygmunta Baumana, Opole: Wydawnictwo Uniwersytetu Opolskiego.

Dijk, T. A. van (2001). Badania nad dyskursem, przeł. G. Grochowski. W: T. A. van Dijk (red.). Dyskurs jako struktura i proces (ss. 9-42). Warszawa: Wydawnictwo Naukowe PWN.

Francuz, P. (2007). Strach i lęk $w$ reklamie politycznej. W: P. Francuz (red.). Psychologiczne aspekty komunikacji audiowizualnej (ss. 213-230). Lublin: Towarzystwo Naukowe KUL.

Hall, S., O’Shea A. (2013). Common-Sense Neoliberalism. Soundings, 55, 9-25. DOI: $10.3898 / 136266213809450194$.

Holmer Nadesan, M. (2008). Governmentality, Biopower, and Everyday Life, New York-Abingdon: Routledge.

Jameson, F. (2011). Postmodernizm, czyli logika kulturowa późnego kapitalizmu, Kraków: Wydawnictwo Uniwersytetu Jagiellońskiego.

La crise du coronavirus, un tournant important pour les medias. Le Figaro (2020). Pobrane z: https://www.lefigaro.fr/medias/la-crise-du-coronavirus-un-tournantimportant-pour-les-medias-20200328.

Lemke, T. (2001). 'The birth of biopolitics': Michel Foucault's lecture at the Collège de France on neo-liberal governmentality. Economy and Society, 30(2), 190-207. DOI: $10.1080 / 03085140120042271$.

Lévy, Y. (2020). La guerre et l'armée: analyse linguistique du discours d'Emmanuel Macron. Pobrane z: https://lundi.am/La-guerre-et-l-armee-analyse-linguistiquedu-discours-d-Emmanuel-Macron.

Rivierre, A. (2020). Champ lexical, figures de style, gestuelle... le discours guerrier de Macron à la loupe. Pobrane z: https://start.lesechos.fr/societe/engagement-societal/ champ-lexical-figures-de-style-gestuelle-le-discours-guerrier-de-macron-a-laloupe-1189061.

Rochegonde de, A. (2020). Coronavirus : les médias sur le pied de guerre. Pobrane z: https://www.strategies.fr/actualites/medias/4042219W/coronavirus-les-medias-sur-le-pied-de-guerre.html.

Simon, J. (2007). Governing Through Crime: How the War on Crime Transformed American Democracy and Created a Culture of Fear, Oxford-New York: Oxford University Press.

Thompson, K. (1999). Moral Panics. London-New York: Routledge.

Vaillant, G. (2020). Coronavirus: de la "guerre» à la "France unie», Emmanuel Macron cherche le ton juste. Pobrane z: https://www.la-croix.com/France/ Politique/Coronavirus-guerre-France-unie-Emmanuel-Macron-cherchejuste-2020-03-31-1201087202.

Virilio, P. (2007). Wypadek pierworodny, Warszawa: Sic!

Warzecha, A. (2014). Krytyczna analiza dyskursu (KAD) w ujęciu Normana Fairclougha. Zarys problematyki. Konteksty Kultury, 11(2), 164-189. DOI: 10.4467/23531991KK.14.011.1757. 
Winczewski, D. (2017). Realizm polityczny Carla von Clausewitza a sprawa polska, Studia Krytyczne / Critical Studies, 4, 151-165.

Zevnik, A. (2017). From Fear to Anxiety: An Exploration into a New Socio-Political Temporality, Law Critique, 28, 235-246. DOI: 10.1007/s10978-017-9211-x. 